\title{
OBSERVATIONS ON ECHENEIBOTHRIUM MACULATUM (CESTODA: TETRAPHYLLIDEA)
}

\author{
By H. HaRFord WiLliams \\ Department of Zoology, University College, Cardiff
}

(Plate I and Text-figs. I-30)

Forty-five specimens of Raia montagui Fowler were recently examined for their cestode parasites and twenty-seven of these contained Echeneibothrium maculatum Woodland, 1927, a species which has not been found in any other elasmobranch. In addition to its well-marked specificity to this host there is an indication that $E$. maculatum prefers to attach itself to a particular region of the intestine. The cestode was not recognized as a valid species by Baylis (I948) and is included as a synonym of E. dubium Van Beneden I858 in the Plymouth Fauna List (Marine Biological Association, 1957), but Williams (1958a) and Euzet (1959) were not in agreement with these views. For this and other reasons a re-investigation of E. maculatum was undertaken.

\section{MATERIALS AND METHODS}

The specimens of Raia montagui were trawled off Plymouth by R.V. 'Sula' during August and September, 1958 and 1959 . The rays were kept alive in the large sea-water tanks outside the laboratory and were examined for their cestode parasites as soon as possible, usually within a period of $24 \mathrm{~h}$. This was found to be necessary because elasmobranchs kept alive under these conditions, presumably without food, have shown a strong tendency to lose their intestinal parasites. It is hoped to discuss this phenomenon more fully elsewhere.

The intestines of some of the fishes were removed from the freshly killed hosts and opened with scissors following the course indicated by the arrowed broken lines in Text-figure 2 . Having been opened in this manner they could be quickly examined as a flat piece of tissue for their cestode parasites (Text-fig. 3). A few intestines were preserved whole in $4 \%$ neutral formaldehyde and were examined at a later date using the method mentioned above or were sectioned vertically (Text-fig. I) for a rapid determination of the exact location of E. maculatum within the gut.

Twenty-two male and twenty-three female specimens of $R$. montagui were examined and of these eleven males and sixteen females harboured E. maculatum. This parasite and the proglottides which it liberates were sometimes present in large numbers, but no record has been made of the exact number present in each fish. As an example of a heavy infestation, however, one small male ray, measuring 6 in. across the wings, harboured 123 strobilae and 503 proglottides. In addition other tetraphyllideans, including another species of 
Echeneibothrium and members of the genera Phyllobothrium, Acanthobothrium, Onchobothrium and Tritaphros, were sometimes found in the fishes infested with $E$. maculatum. Woodland (1927) referring to $E$. maculatum stated that 'this small form is fairly common in $R$. maculata $[=R$. montagui] at Plymouth, it having been found in eighteen out of the forty-seven fish examined' and according to Baylis (1948), who examined seventeen specimens of $R$. montagui, E. maculatum is 'often present in hundreds'.

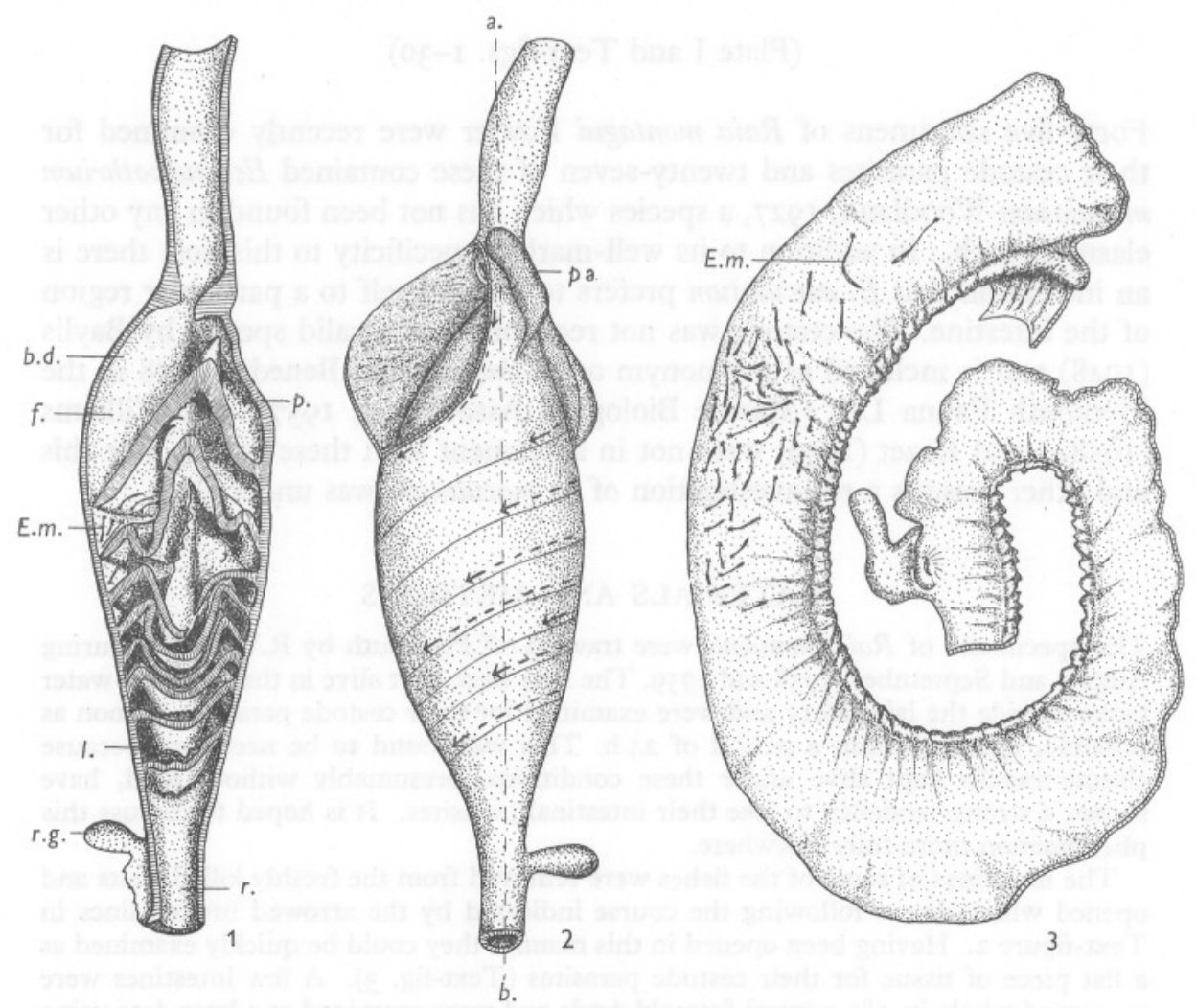

Text-figs. $\mathrm{I}-3$. Intestine of Raia montagui showing method used in determining location of $E$. maculatum. $a-b$, axis along which intestine was sectioned; b.d., approximate position of bile duct opening into intestine; E.m., E. maculatum; $f$., first chamber of spiral valve intestine; $l$., last chamber of spiral valve intestine; $p$., approximate position of pancreatic duct opening into intestine; pa., pancreas; r., rectum; r.g., rectal gland.

In order to study the anatomy of E. maculatum, living specimens were examined in a drop of sea water on a slide and, in some instances, the scolex was examined while still attached to a piece of intestine. The results obtained from living specimens were later confirmed by a detailed examination of material which had been fixed in $4 \%$ neutral formaldehyde, Bouin's or Gilson's fluids. Temporary mounts of fixed specimens were studied under a coverslip in water, lactophenol, or a solution of $5 \%$ glycerine in 
alcohol. For permanent whole mounts Paracarmine, Ehrlich's haematoxylin or Acetocarmine were used as stains and the specimens cleared in xylene, clove oil or methyl benzoate. Unstained whole mounts were also prepared and found useful for an examination of the scolex while still attached to the gut. Some features of the anatomy of E. maculatum, for example, the cirrus spines (Text-figs. 29, 30) and the spines found on the scolex (Text-fig. 4) are well seen in mounts made in polyvinillactophenol, a method used by Thompson (1958) for an examination of the radula of Adalaria proxima. Serial sections cut in three planes, transverse, horizontal and sagittal, were stained with Mallory's triple stain, Heidenhain's haematoxylin with Ponceau S, or with Trioxyhaematin.

\section{ECOLOGY}

It has been found that $E$. maculatum appears to prefer a particular region of the intestine of $R$. montagui (Text-figs. I, 3). Very few specimens were found in the first chamber of the spiral valve while the greatest concentration occurred in the second and third compartments. The number decreased in the fourth chamber and no specimens were found behind this region. Although the greatest concentration of attached strobilae was found in these locations the largest number of free proglottides always occurred in the anterior chamber of the intestine. This interesting phenomenon was also observed by Euzet (1959) in other tetraphyllideans and was recently confirmed by the writer. The best example appears to be the adult of Orygmatobothrium musteli from Mustelus mustelus, the scolex of which is attached to the posterior region of the intestine while large numbers of its proglottides accumulate in the anterior part of the gut. This suggests that an anterior migration of the proglottides occurs within the intestine but whether E. maculatum behaves in a similar manner is not known. It may be that in this latter species it is only those strobilae which are attached within the anterior chamber of the intestine that are responsible for liberating proglottides. The fact that the worms are invariably larger in size than those situated more posteriorly in the gut suggests that there may be a greater concentration of available food for them in this location or alternatively that the presence of fewer worms results in less severe competition for the same concentration of food. At present little is known of the metabolic requirements of Tetraphyllidea in relation to the production of proglottides and reproduction.

In addition to their tendency to concentrate in the second and third compartments, the specimens of E. maculatum, in the majority of the fishes examined, appeared to avoid attaching themselves near the central longitudinal food channel which runs through the intestine. This is interesting but perhaps not unusual behaviour as other parasites have been found to select well protected habitats, for example, Kabata (1959) obtained a similar result with parasitic copepods of the genus Acanthochondria. 


\section{ANATOMY OF ECHENEIBOTHRIUM MACULATUM}

\section{External features of the scolex}

The very brief accounts of the scolex given by Woodland (I927) and Euzet (1959) need supplementing.

The scolex is composed of a myzorhynchus and four pedunculated, spoonshaped bothridia which are divided into loculi (Text-figs. 4, II). It exhibits very little movement in living specimens that are still attached to the intestine (Text-fig. 8) but immediately becomes very active on being forcibly detached, the myzorhynchus and bothridia expanding and contracting continuously. The worms re-attach themselves readily to the intestine of a freshly killed $R$. montagui, the myzorhynchus as well as the apex of each bothridium appearing to function in the first instance as probing organs until a suitable position for attachment is found, and then as organs of adhesion. The bothridia of the scolex, while still attached to the intestine, cover an area of about $\mathrm{I} . \mathrm{O} \mathrm{mm}$ in diameter and the myzorhynchus may be $\mathrm{I} .0 \mathrm{~mm}$ in length and $0.07 \mathrm{~mm}$ in diameter (Text-fig. 8). In detached specimens this latter organ may contract to $0.2 \mathrm{~mm}$ in length by $0.18 \mathrm{~mm}$ in diameter and assume a variety of shapes (Text-figs. 5, 7, 22) while the loculate surface of a bothridium measures about $0.5 \mathrm{~mm}$ in length and $0.25 \mathrm{~mm}$ in breadth. The above measurements were recorded from stained whole mounts.

It is often extremely difficult and sometimes impossible to determine the exact number of loculi within each bothridium when examining fixed stained specimens, but it has been observed, from living material, that there are usually eighteen but occasionally twenty loculi present. Woodland (I927) recorded only fifteen or seventeen loculi. Each bothridium possesses minute cuticular spines covering most of its convex or inner surface (Text-figs. 4, I2, I6), a feature not previously mentioned. Even smaller spines are present on the outer concave or loculate side of the bothridium (Text-fig. I2). It is not known whether these spines assist in attaching the parasite to the gut as no specimens have been found in which they were actually piercing or even closely adhering to the epithelial cells of the mucosa. Possibly they are defensive structures preventing the scolex from being crushed and therefore damaged when the folds of the mucosa move towards each other during peristalsis which has been observed to be extremely active in freshly killed rays. The presence of minute cuticular spines is a very characteristic feature of the scolex in other members of the genus Echeneibothrium but most previous descriptions do not mention this feature. The presence of deep corrugations or grooves on the inner or convex surface of the bothridium (Text-fig. I7) is another interesting but previously unrecorded character of E. maculatum. These may be a provision to allow for expansion of the body wall without the actual stretching of the cuticle which may not be as readily expansible as the unstriated muscles within the bothridium. Manton (1959) is of the opinion 


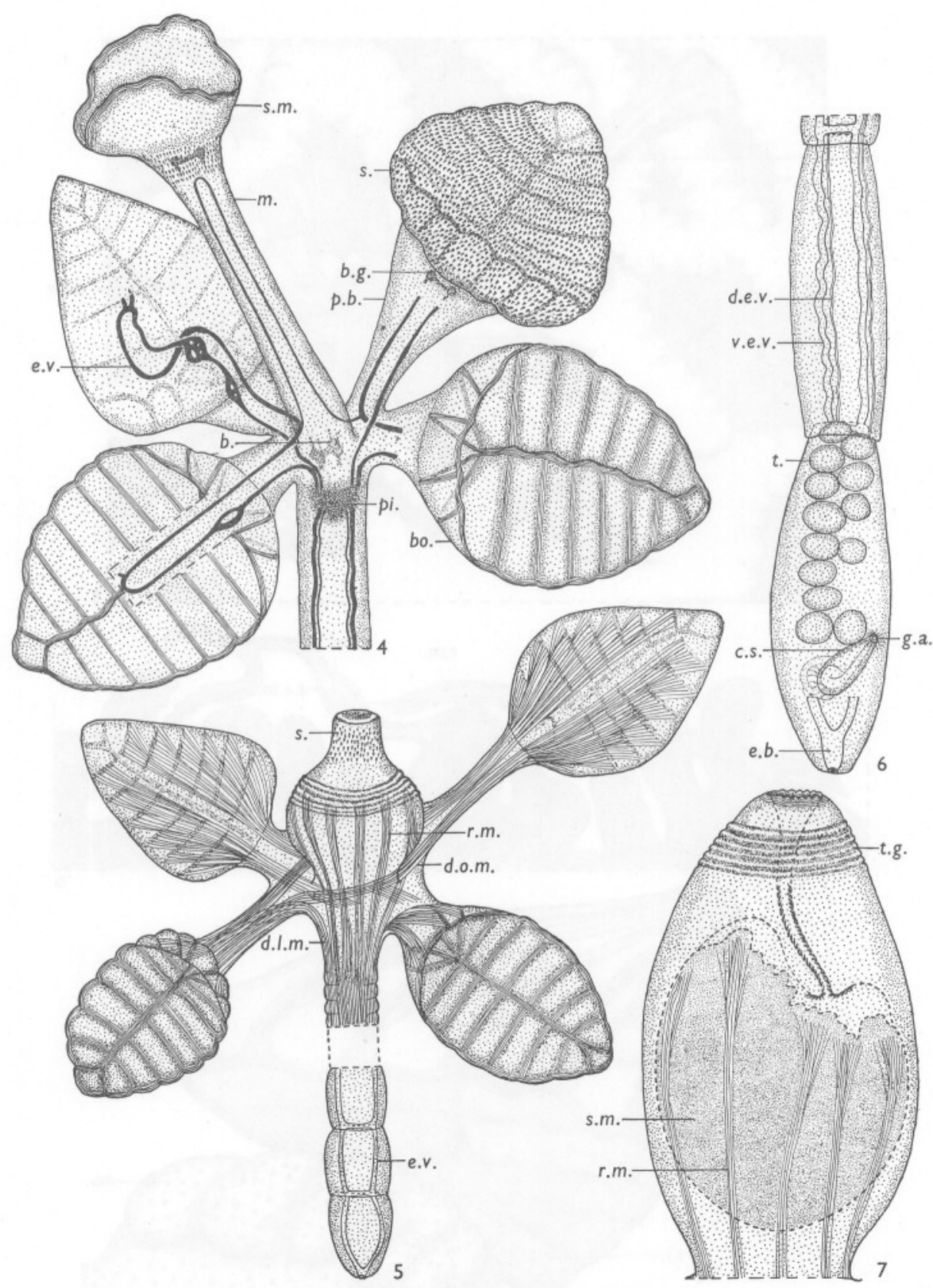

Text-figs. 4-7. Echeneibothrium maculatum.

Fig. 4. Scolex of a mature individual in which are shown parts of the nervous and excretory systems.

Fig. 5. Scolex of an immature specimen with twelve proglottides, drawn to same scale as Fig. 4 .

Fig. 6. Posterior proglottides of an immature individual showing only thirteen testes.

Fig. 7. Contracted myzorhynchus with retracted sucker.

b., brain; b.g., bothridial ganglion; bo., bothridium; c.s., cirrus sac; d.e.v., dorsal excretory vessel; d.l.m., deep longitudinal muscles; d.o.m., deep oblique muscles; e.b., excretory bladder; e.v., excretory vessel of bothridium; g.a., genital atrium; m., myzorhynchus; p.b., peduncle of bothridium; pi., red 'pigmented' region; r.m., retractor muscles; s., spines; s.m., apical sucker of myzorhynchus; $t$., testis; t.g., transverse grooves; v.e.v., ventral excretory vessel. 

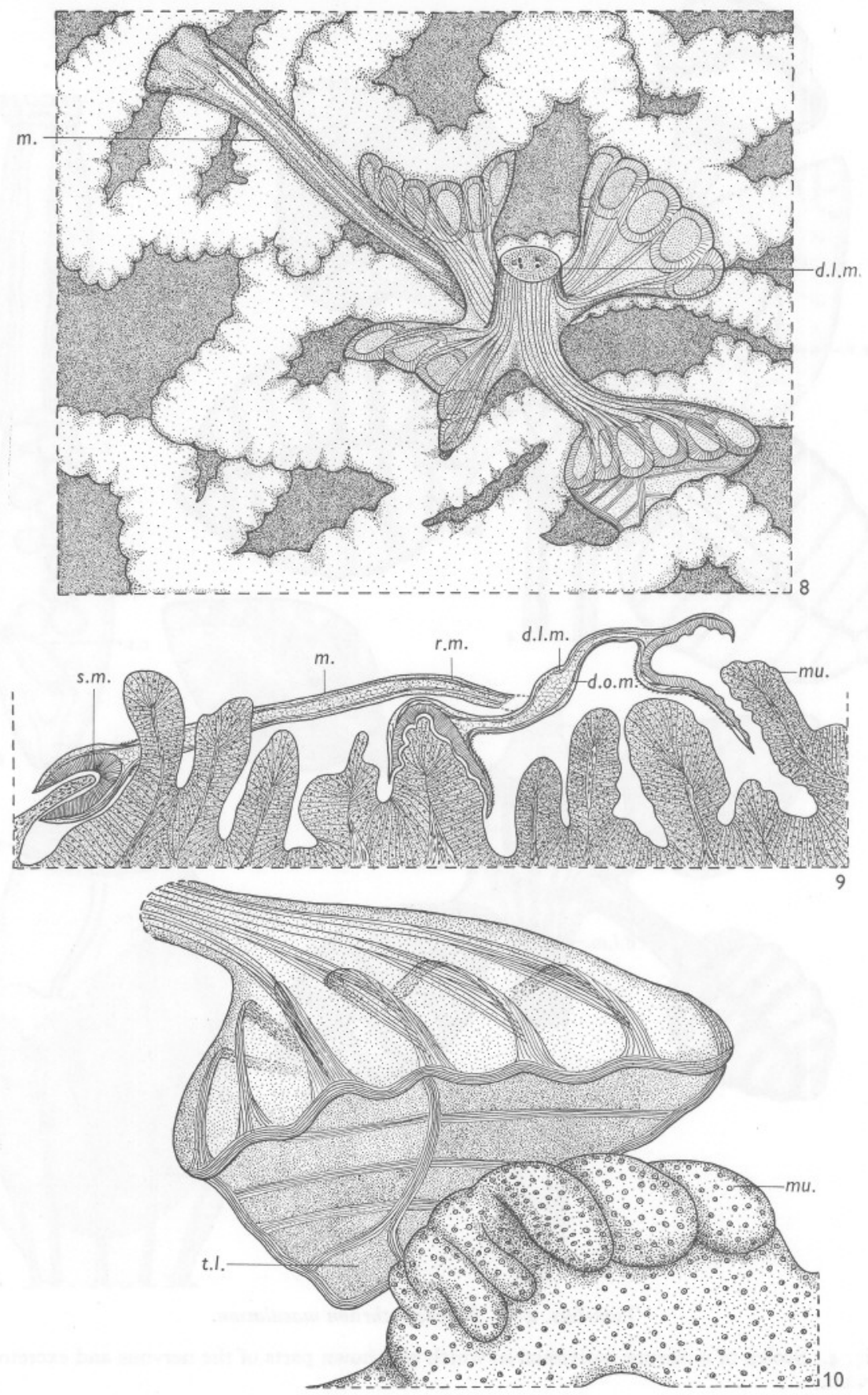

Text-figs. 8-I0. Echeneibothrium maculatum.

Fig. 8. Showing orientation of bothridium and myzorhynchus while attached to the mucosa of the intestine.

Fig. 9. Section through scolex attached to intestine.

Fig. Io. Showing natural position and shape of bothridium when attached to a portion of the mucosa which, in this case, shows a distinct imprint of some of the posterior loculi.

d.l.m., deep longitudinal muscles; d.o.m., deep oblique muscles; m., myzorhynchus; mu., mucosa; r.m., retractor muscles; s.m., apical sucker of myzorhynchus; t.l., anterior terminal loculus of bothridium. 
that a furrowed cuticle may serve this function in some arthropods. The myzorhynchus is an extremely variable organ capable of extending to at least five times the length it assumes when fully contracted. Furrows or grooves are present in its body walls (Text-figs. 7,22 ), which again may enable the organ to reach considerable length in its search for a suitable area to attach itself.

Woodland (1927) mentioned briefly the extreme variability in the length of the myzorhynchus and described the extremity of this organ as a 'thick pad covered with a circular fold of the terminal subcuticula save for a small central opening' (see Text-fig. 9) and stated that it resembled a sucker when retracted. The presence of a powerful functional sucker at the apex of the myzorhynchus is confirmed; but it may be completely withdrawn into the organ (Text-figs. 7, 9, 20-23) by means of powerful retractor muscles. When the myzorhynchus is fully expanded conspicuous cuticular spines are clearly visible in the region immediately behind the apical sucker (Text-figs. 4, 22). These spines, not mentioned in previous descriptions, may become inverted and lie within the myzorhynchus when it is fully contracted (Text-fig. 7).

\section{Musculature}

Accounts of the main groups of muscles to be found in Tetraphyllidea have been given by Rees (1946, 1953) for Phyllobothrium dohrnii and a species of the genus Echeneibothrium, respectively.

The present description, therefore, will deal mainly with the musculature of the scolex because, so far as I am aware, a study of this system in relation to the function of the scolex has not been previously investigated in the genus.

The musculature of the strobila will not be described, as adequate descriptions are available. Woodland (1927) noted in E. maculatum 'the absence of a distinct internal layer of longitudinal muscle fibres and bundles of fibres throughout the subcuticular layer'. The writer's observations on transverse sections, however, indicate that muscle fibres are present, but are difficult to detect at the posterior end of the strobila and in the free proglottides, possibly due to the expansion of the uterus on becoming filled with eggs. That powerful longitudinal muscles are present is clearly indicated by the continuous contraction and expansion of living worms and proglottides.

When viewed in longitudinal and transverse sections it becomes evident that the bothridium functions as a large shallow sucker enveloping the host's epithelial tissue (Text-figs. I4, I6). The size of the bothridial opening appears to be controlled by muscles which may be derived from the longitudinal superficial muscle fibres of the body wall, these having become concentrated around the margins of the opening (Text-fig. II, m.s.). The main cavity of the bothridium is divided into eighteen or twenty loculi which result from a particular arrangement of the superficial musculature in its wall. There is a distinct group of median longitudinal superficial muscle fibres (m.l.s.) which divides 

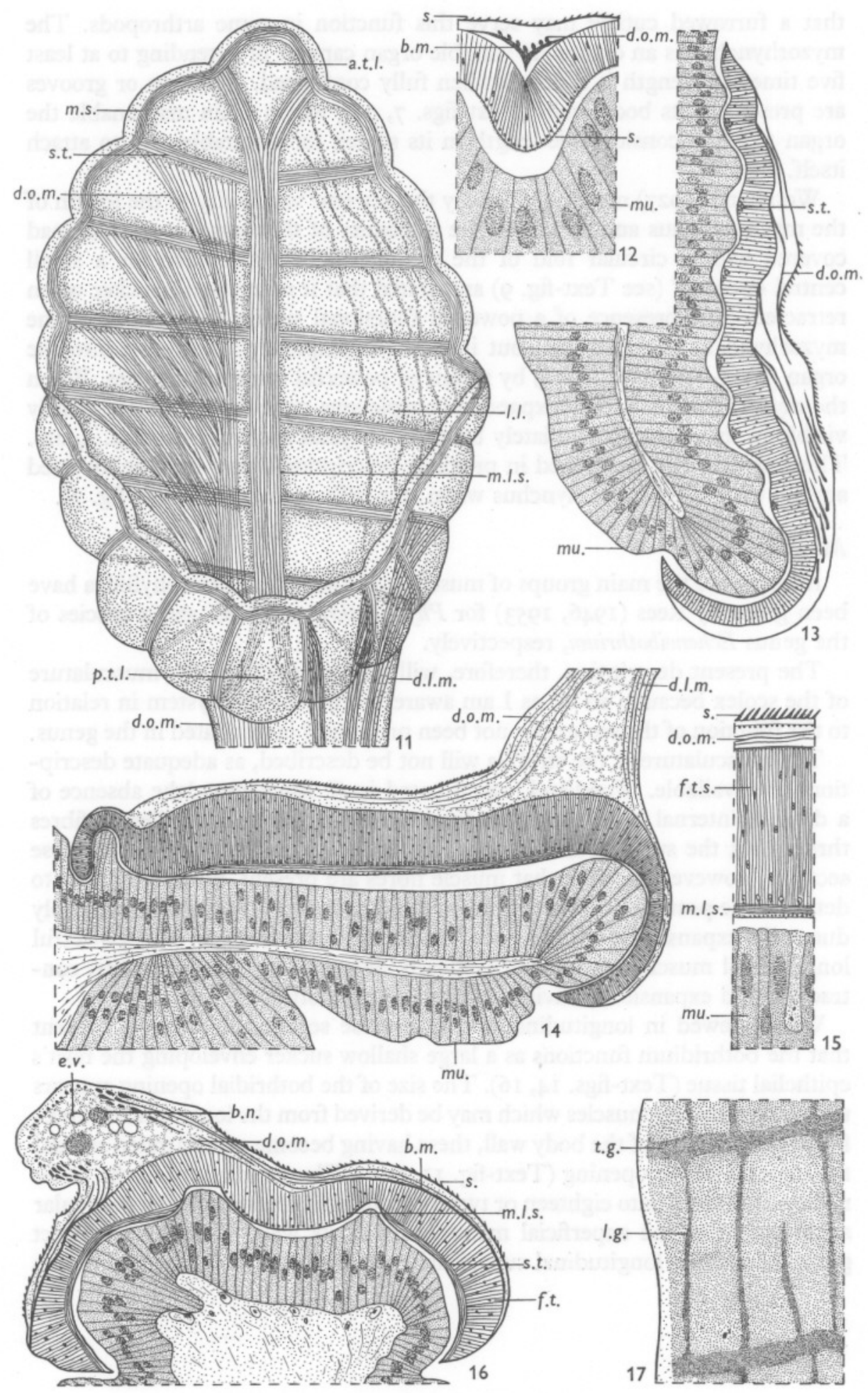

Text-figs. II-I7. For legends see opposite page. 
the bothridium into two equal halves. At each extremity of the bothridium this group of longitudinal muscle fibres diverges into two and the fibres become attached to the basement membrane of the body wall, thus forming two terminal loculi (a.t.l., p.t.l.). Each half of the bothridium is further subdivided by seven or eight groups of transverse superficial muscle fibres (s.t.). This arrangement appears to be the result of a concentration of the circular muscle fibres in particular regions of the body wall resulting in the formation of eight or nine lateral loculi (l.l.). The ends of these muscle fibres (Textfig. I6, s.t.) are attached to the basement membrane in the wall of the bothridium. The effect of the above arrangement of the musculature within the bothridium is to form eighteen or twenty subsidiary 'suckers' or loculi, each of which envelops a small portion of the host tissue that is covered by the whole bothridium. A contraction of the muscles which form the loculi would obviously result in a firmer grip of the tissue. The effect of such an attachment of each loculus or 'sucker' can be seen in Text-fig. Io, the mucosa of the intestine showing an imprint of the posterior loculi of a bothridium.

The deep longitudinal muscle fibres at the base of the scolex of E. maculatum are arranged in a uniform ring (Text-fig. 8, d.l.m.), but on entering the scolex some spread out into the peduncles of the bothridia (Text-figs. 5, 9) and others into the myzorhynchus. In this latter organ the musculature becomes arranged into about thirteen separate bundles each containing seven to twelve muscle fibres (Text-fig. I9, r.m.). These muscle bundles form the retractor muscles of the apical sucker of the myzorhynchus (Text-figs. 20, 23). They function in withdrawing the sucker into the myzorhynchus (Text-fig. 7). The length and diameter of the myzorhynchus is probably controlled by the superficial circular and longitudinal muscles of its body wall.

The deep longitudinal muscle fibres, after entering the bothridium, are arranged in distinct bundles. The muscle fibres of each bundle spread out fanwise within the bothridium, their endings becoming attached to the base-

Legends to Text-figs. II-I7.

Echeneibothrium maculatum showing the anatomy of a bothridium.

Fig. II. Ventral view of bothridium showing loculi and main musculature.

Fig. 12. Portion of Fig. 13 in greater detail showing thickened basement membrane.

Fig. 13. Lateral longitudinal section through bothridium attached to the gut.

Fig. I4. Median longitudinal section through bothridium.

Fig. 15. Portion of Fig. I4 in greater detail.

Fig. I6. Transverse section through bothridium.

Fig. 17. Part of convex or dorsal side of bothridium showing grooves in the cuticle.

a.t.l., anterior terminal loculus; b.m., basement membrane; b.n., bothridial nerve; d.l.m., deep longitudinal muscles; d.o.m., deep oblique muscles; e.v., excretory vessel; f.t., fibrous tissue; l.g., longitudinal groove; l.l., lateral loculus; m.l.s., median longitudinal superficial muscles; m.s., marginal superficial muscles; mu., mucosa; p.t.l., posterior terminal loculus; s., spines; s.t., superficial transverse muscles; t.g., transverse groove. 
ment membrane of the fibrous tissue layer. It is interesting to note that the muscle fibre endings of each bundle are attached in a particular manner and region, that is to considerably thickened areas of the basement membrane which are situated transversely to the long axis of the bothridium, to the inner side of the fibrous tissue layer and between the loculi.

There is also present a system of deep oblique muscles (Text-figs. 5, II, d.o.m.), the bundles of fibres crossing one another in the centre of the scolex (Text-fig. 2I, d.o.m.) and then extending into the peduncles of the bothridia. This system of muscles, like the deep longitudinal muscles, becomes attached in particular regions to thickened areas of the basement membrane (Text-figs. I I, I6, d.o.m.).

A consideration of the structure in relation to the natural position of the bothridium when attached to the host's tissue (Text-figs. 8, 9, I4) shows quite clearly that a contraction of the deep longitudinal and deep oblique muscles would result in the withdrawal of the bothridium from the mucosa.

\section{Nervous system}

The nervous system of $E$. maculatum has not been described previously although it exhibits some interesting features. There is a prominent 'brain' (Text-figs. 4, I8) giving off nerves to the strobila, bothridia and myzorhynchus. The 'brain' is in the form of two bilobed ganglia connected by a transverse commissure and is centrally situated at about the level of the junctions of the peduncles of the bothridia with the scolex (Text-fig. 2I). From each ganglion of the 'brain' a pair of lateral longitudinal nerves extends posteriorly to run the length of the strobila (Text-fig. I8, l.n.). A pair of nerves arises from each of the four lobes of the 'brain' to extend into the four bothridia (b.n.) slightly posterior to the junction of the peduncle and bothridium. The two ganglia in each peduncle are joined by a ring commissure (b.c.). In addition four nerves arise from the brain (Text-fig. I8, m.n.) and after extending anteriorly almost as far as the sucker of the myzorhynchus join with a ring commissure which

\section{Legends to Text-figs. I8-23. \\ Echeneibothrium maculatum.}

Fig. I8. Diagram of nervous system of the scolex.

Fig. 19. Transverse section of the myzorhynchus showing the ganglia and commissure.

Fig. 2r. Transverse section of the scolex in the region of the 'brain'.

Figs. 20, 22, 23. To show variation in the shape of the myzorhynchus and its apical sucker. Figs. 20, 23. Median longitudinal sections. Fig. 22. Drawn from whole mount.

b., 'brain'; b.c., bothridial commissure; b.g., bothridial ganglion; b.n., bothridial nerve; d.o.m., deep oblique muscles; e.v., excretory vessel; g.m., ganglion of myzorhynchus; h.t.c., host tissue cells; l.n., longitudinal nerve to strobila; m.c., circular commissure of myzorhynchus; m.n., nerve to myzorhynchus; n.c., nerve cell; r.m., retractor muscles; s., spines; s.m., apical sucker of myzorhynchus; t.c., transverse commissure of 'brain'; t.g., transverse groove in cuticle of myzorhynchus. 


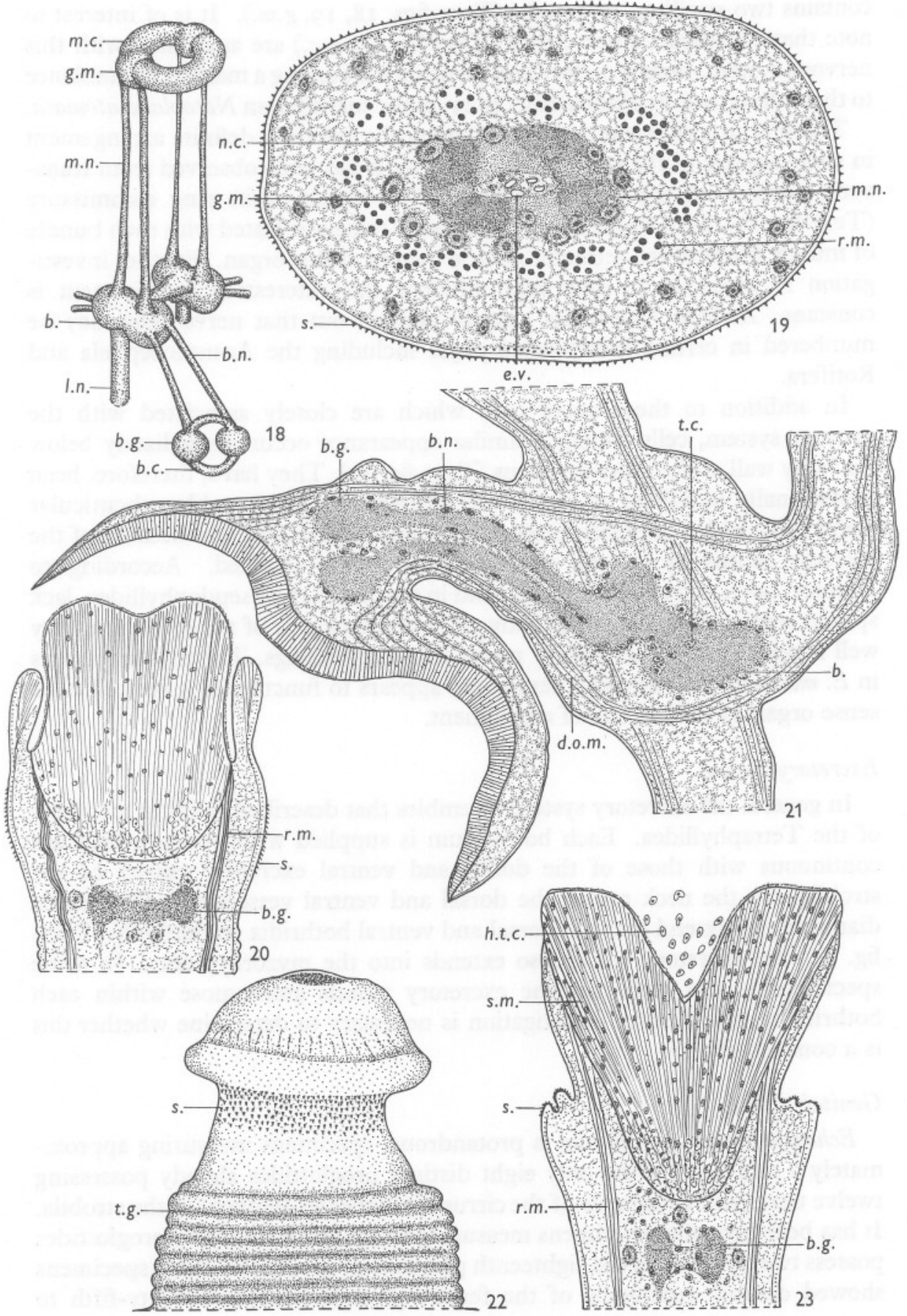

Text-figs. 18-23. For legends see opposite page. 
contains two swellings or ganglia (Text-figs. I8, I9, g.m.). It is of interest to note that conspicuous nerve cells (Text-fig. 19, n.c.) are associated with this nervous system, their structure and distribution bearing a marked resemblance to those described by Hadenfeldt (1929) in the turbellarian Notoplana atomata.

There is an indication that these nerve cells exhibit a definite arrangement in some regions of the scolex. For example, it has been observed from transverse sections of the myzorhynchus in the region of its ring commissure (Text-fig. I9) that a single nerve cell appears to be associated with each bundle of muscle fibres of the retractor muscle system of this organ. Further investigation is necessary to determine whether this interesting arrangement is constant. Andrew (1959) has already pointed out that nerve cells may be numbered in certain invertebrate phyla including the Acanthocephala and Rotifera.

In addition to these nerve cells which are closely associated with the nervous system, cells having a similar appearance occur immediately below the body wall of the myzorhynchus (Text-fig. I9). They have, therefore, been provisionally identified as nerve cells as they do not resemble subcuticular gland cells, which are often present in helminth parasites, and because of the extreme sensitivity of the myzorhynchus when touched. According to Hyman (I95I, p. 253) the Cestoda, and in particular the Pseudophyllidea, lack special sense organs while the body surface and organs of the scolex are very well supplied with free sensory nerve cells and endings. The myzorhynchus in E. maculatum, as already mentioned, appears to function as a very efficient sense organ as well as one of attachment.

\section{Excretory system}

In general the excretory system resembles that described in other members of the Tetraphyllidea. Each bothridium is supplied with vessels which are continuous with those of the dorsal and ventral excretory vessels of the strobila. In the neck region the dorsal and ventral vessels are of the same diameter and extend into the dorsal and ventral bothridia respectively (Textfig. 4). An excretory vessel also extends into the myzorhynchus. In some specimens it was seen that the excretory vessels anastomose within each bothridium, but further investigation is necessary to determine whether this is a constant feature.

\section{Genital system}

Echeneibothrium maculatum is protandrous, specimens measuring approximately $2 \mathrm{~mm}$ and having only eight distinct proglottides already possessing twelve testes and rudiments of the cirrus sac in the last segment of the strobila. It has been seen that specimens measuring $6 \mathrm{~mm}$ and with thirty proglottides possess twenty testes in the eighteenth proglottid. In addition these specimens showed distinct rudiments of the female genitalia in their twenty-fifth to 
thirtieth proglottides. The total number of proglottides in strobilae showing every indication of being mature and of being in the process of liberating proglottides varies from 30 to 100 , the latter number having been recorded in individuals $100 \mathrm{~mm}$ long. The average length and breadth of the posterior proglottid in fixed mature specimens is about $\mathrm{I} .8$ and $0.5 \mathrm{~mm}$, respectively. Apparently the end proglottid becomes detached from the body soon after egg production has begun and the liberated proglottid may then continue to grow while it is free in the intestine, reaching a length of $4 \mathrm{~mm}$ and a diameter of $\mathrm{I} \mathrm{mm}$, these again being measurements of individuals fixed in $4 \%$ neutral formaldehyde. At this size the proglottides are fully distended with eggs as a result of the expansion of the uterus, and only vestiges of the male and female genitalia remain. As egg production progresses a degeneration has been noticed of the posteriormost testes of the proglottid. This is interesting because in immature individuals the first testes to appear are those in the posterior regions of the segments. It may be important to bear this in mind while using the number of testes as a taxonomic character. The ducts of the male and female genitalia open into a genital atrium, the pores being irregularly alternate and situated laterally, slightly in front of the posterior third of the proglottid (Text-fig. 26). The other features of the male and female genitalia are described separately below.

Male genitalia. There are usually twenty testes in each mature segment, but occasional specimens were found in which there were twenty-four, and in one liberated proglottid thirty-four were counted. The testes are arranged roughly in two rows almost meeting in the middle line, occupying two-thirds of the length of the proglottid and not usually extending behind the level of the cirrus sac (Text-fig. 26). They are spherical and situated dorsally to the uterus. No vasa efferentia have been seen, but the vas deferens which may be functioning as a vesicula seminalis is very long and coiled, occupying a dorsal position in the middle line, behind the testes and in front of the ovary. The vas deferens is continuous with a cirrus that is situated within the cirrus sac which measures $0.35 \times 0.15 \mathrm{~mm}$. The cirrus, which is well armed with minute spines (Text-fig. 30) measuring about $0.016 \mathrm{~mm}$, opens into the genital atrium. According to Woodland (1927) the cirrus when fully extruded appears to exceed the length of the whole proglottid but the writer is unable to confirm this interesting observation. The cirrus when extended is certainly very long, a fact which may well have some connexion with the length of the vagina. No specimens were observed, however, in which the cirrus was inserted into the vagina of its own segment. This has been observed in some Tetraphyllidea, for example, Phyllobothrium sinuosiceps Williams, 1959, in which self-fertilization occurs. At present there is no evidence that selffertilization occurrs in E. maculatum, but cross-fertilization of a liberated proglottid with another appears to be unlikely since, of the hundreds of proglottides which have been seen, none were united in copulation. 


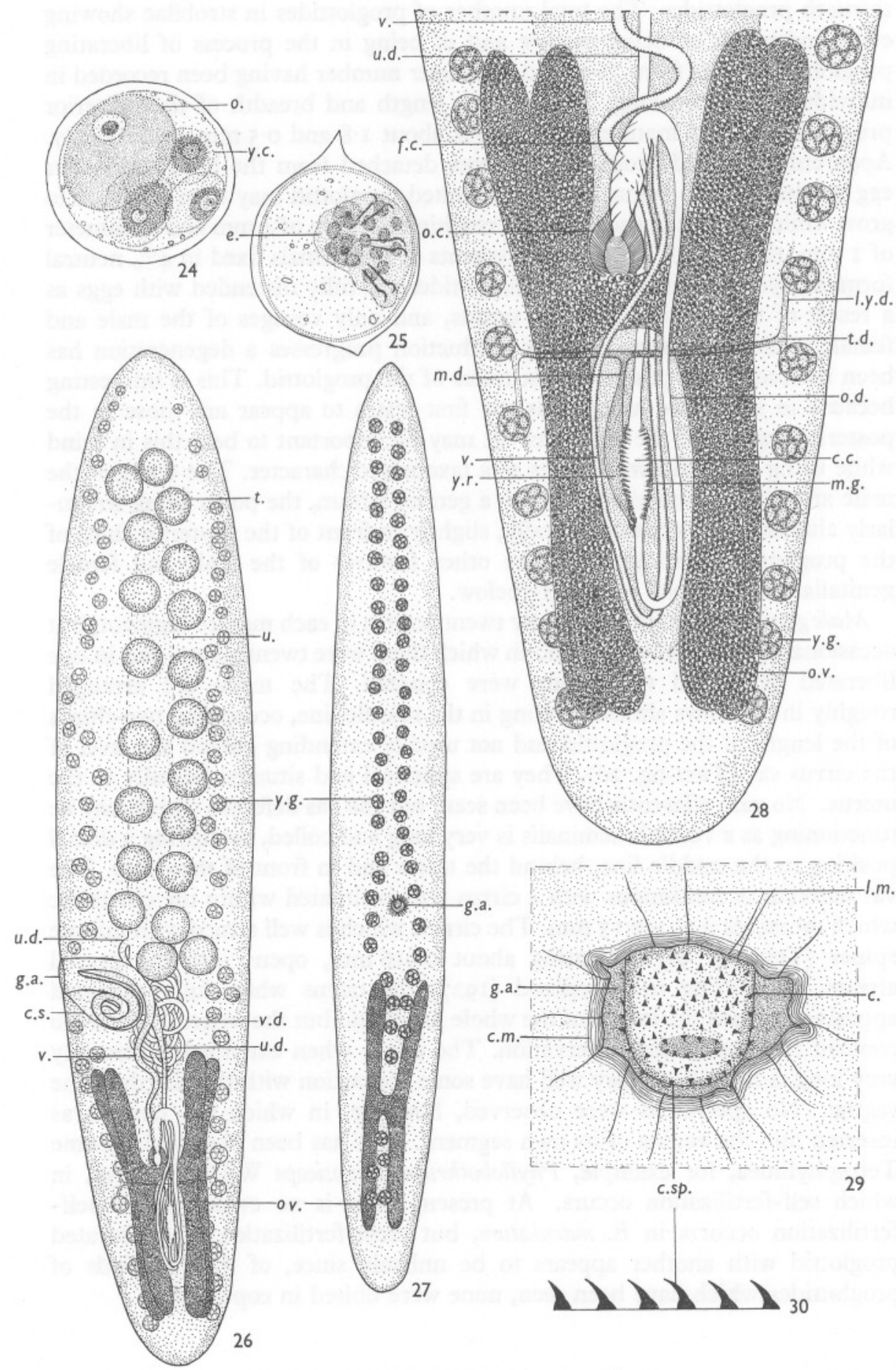

Text-figs. 24-30. For legends see opposite page. 
Female genitalia. The ovary is situated posteriorly, lying behind the coils of the vas deferens. It is roughly $\mathrm{H}$-shaped in dorsal, ventral and lateral views (Text-figs. 26, 27), as it possesses eight almost cylindrical branches projecting from a short transverse limb. The oviduct arises as a distinct ovicapt in the middle line from the anterior border of the transverse limb of the ovary and continues anteriorly in the form of a dilated valvular structure (Text-fig. 28) described as the 'fertilization chamber' by Woodland (1927). This may also function in preventing the ova from returning towards the ovary as a result of the suction pressure that is probably set up on the contraction of the powerful muscular wall of the ovicapt. The 'fertilization chamber' receives the vagina at its anterior border and then changes its course to proceed ventrally and backwards as the oviduct, almost as far as the posterior extremity of the ovary. Here it loops dorsally to take an anterior course and receives the median yolk duct immediately before dilating to form the dorsal central chamber or ootype surrounded by Mehlis's gland. The uterus emerges from the ootype as a slightly sinuous duct, which continues anteriorly in the mid-dorsal line to open, near the level of the genital pore, into the dorso-lateral side of the saclike ventral uterus. No uterine pores opening to the exterior have been seen, the eggs being liberated into the sea presumably as a result of the rupture of the ventral body wall. This invariably occurs when fully gravid proglottides are placed in a vessel containing sea water.

From its external opening into the genital atrium the vagina takes a lateral course as far as the middle line where it turns sharply backwards. It runs posteriorly directly above the uterus as far as the 'fertilization chamber', becoming gradually dorsal in this region, and then continues backwards almost as far as the posterior extremity of the ovary. Here it loops ventrally taking an anterior course to open into the 'fertilization chamber'.

The yolk glands occur in the form of a double row of follicles on either side of the proglottid and extend along most of its length (Text-figs. 27, 28). The yolk ducts are first apparent as lateral longitudinal collecting tubules on either

Legends to Text-figs. 24-30.

Echeneibothrium maculatum showing male and female genitalia.

Figs. 24, 25. Two stages in the development of an egg.

Fig. 26. Proglottid in ventral view (the outline only of the uterus is included).

Fig. 27. Another proglottid in lateral view to show the arrangement of the yolk gland.

Fig. 28. Posterior region of a proglottid to show the arrangement of the female ducts.

Fig. 29. Genital atrium and base of withdrawn armed cirrus.

Fig. 30. Spines from base of cirrus.

c., cirrus; c.c., central chamber or ootype; c.m., circular muscle; c.s., cirrus sac; c.sp., cirrus spines; e., embryo; f.c., 'fertilization chamber'; g.a., genital atrium; l.m., longitudinal muscle; l.y.d., lateral yolk duct; m.d., median yolk duct; m.g., Mehlis's gland; o., ovum; o.c., ovicapt; o.d., oviduct; ov., ovary; $t$., testis; $t$.d., transverse yolk duct; $u$., uterus; $u . d$. , uterine duct; $v$. , vagina; v.d., vas deferens; y.c., yolk cell; y.g., yolk glands; y.r., yolk reservoir. 
side of the transverse limb of the ovary. In this region they join to form a transverse yolk duct from which the median yolk duct extends posteriorly, in the middle line. This latter duct is dilated to form a yolk reservoir before it opens into the oviduct in the neighbourhood of Mehlis's gland. Its opening appears to be surrounded by a small sphincter muscle (Text-fig. 28).

Some unforeseen problems have arisen in attempting to study the eggs and egg-shell formation in E. maculatum in relation to the structure of the genitalia. As far as can be ascertained at present, the eggs of the species when in an early stage of development are spherical in shape and possess an ovum surrounded by two or three yolk cells all of which are enclosed by at least two distinct membranes (Text-fig. 24). In some eggs, however, the ovum had already absorbed the contents of the yolk cells and had become a hexacanth embryo measuring about $0.013 \mathrm{~mm}$ in diameter (Text-fig. 25). As can be seen from this figure some of the eggs possess distinct processes or foldings on the outer shell wall. The eggs of E. maculatum measure $0.035 \mathrm{~mm}$ in diameter. According to Woodland (1927) in his specimens the eggs measured $0.055 \mathrm{~mm}$, possessed six hooks, and were in 'clusters' when first deposited in the uterus. In other Tetraphyllidea from $R$. montagui it has been found that the eggs occur in 'clusters' and measure about $0.053 \mathrm{~mm}$. It is possible therefore that Woodland may have been examining the eggs of a species other than E. maculatum.

\section{A DISCUSSION OF THE SPECIFICITY OF ECHENEIBOTHRIUM $M A C U L A T U M$ TO RAIA MONTAGUI}

Echeneibothrium maculatum appears to occur only in $R$. montagui, but according to Euzet (1959) a variety, E. maculatum var. exiguum, is sometimes present in $R$. clavata. As a result of an investigation of this 'variety' an account of which will be published at a later date, the writer is of the opinion that it may well be a distinct species. It is now thought that at least three main factors, namely, ecological, morphological and physiological, contribute towards restricting E. maculatum to one host species. Two of these factors are discussed briefly below. Although physiological factors cannot be considered here it is thought that advances in this field will add much towards an understanding of the host-specificity shown by these cestodes.

\section{Ecological factors}

Steven (1932) has shown that shoals of at least three members of the genus Raia are sometimes unispecific and possibly at certain times of the year unisexual. He also stated that there is some evidence for believing that the various species do not show extensive migratory movements. These observations are supported by Gerking (1959) who was of the opinion that many species of fish tend to remain in a particular area and even defend their territories against 
intruders. If other species of Raia do not often enter areas occupied by $R$. montagui their chances of becoming infested with Echeneibothrium maculatum would certainly be diminished.

Little is known of tetraphyllidean life-histories, but from the available information it is reasonable to assume that $R$. montagui acquires E. maculatum by eating some animal which harbours the plerocercoid stage of the cestode. If this plerocercoid larva is also specific to the intermediate host then the food of $R$. montagui would be important in determining its cestode parasites. Euzet (1959) has already suggested that the plerocercoid stages of species of the genus Echeneibothrium may be specific to certain decapod crustacea of the order Anomura, but he also expressed the view that members of the genus Raia harbour different parasites, although their food is very similar. In addition, according to Steven (1947), rays are not specific in their feeding habits, but it was pointed out that little is known of this aspect of their biology.

In view of the alleged similarity in the food of rays it is possible that R. montagui ingests, while feeding, many species of the genus Echeneibothrium. A careful search of the intestine and its contents in freshly killed rays, however, suggests that $R$. montagui in Plymouth waters acquires in its food only two species of the genus Echeneibothrium, namely, E. maculatum and another species which may be $E$. fallax. The latter species shows every indication of being very unsuccessful in view of the number present, usually two to three specimens, and the immense host-tissue reaction to the parasite. E. maculatum on the other hand flourishes possibly as a result of its apparently very high degree of adaptation for attachment. So far there have been no indications whatsoever that larval stages of other species of Echeneibothrium are acquired by $R$. montagui and that these fail to establish themselves within the host. The above comments therefore suggest, but do not prove, that $R$. montagui is more selective in its feeding habits than hitherto believed. In addition it has been found that many species of the genus Echeneibothrium are specific to other rays and that according to the literature, as already mentioned, larval stages may well be specific to their intermediate hosts. Thus further detailed investigations should be made into the feeding habits of these fishes. Preliminary observations made at Plymouth support this view. For example, it was noted that polychaete worms, together with many crustaceans, formed an important part of the diet of twenty-one specimens of $R$. montagui, while no polychaetes were found in the stomachs of the twenty-five specimens of $R$. clavata that were examined. Fish remains, including many sand eels but no crustaceans or polychaetes, were found in the stomachs of seven specimens of $R$. brachyura and in three examples of $R$. micro-ocellata. Furthermore, according to Clark (1922), there were differences, although slight, in the stomach contents of young specimens of four species of Raia, and these variations are, in the writer's opinion, significant in investigations into the parasites of rays. 
Differences in the structure of the mucosa of various rays have already been pointed out by Williams (1960) and work is now in progress on the possible correlation between these variations and the food taken by the fishes. The results from an investigation into this kind of relationship will, as Barrington (1957) and Andrew (1959) have pointed out, require a very careful analysis. The papers by Al-Hussaini (1949), Burnstock (1959) and Hinde (1959) indicate that a correlation may well occur between feeding habits and the structure of the intestine in some teleost fishes.

Some of the comments made above support the view expressed by Baylis (1938) that the habits, particularly as regards food and environment of the hosts, have played an important part in determining their helminth fauna. They also agree with the opinion of Prof. Jean Baer, who according to Cameron (1950) recognized two types of host-specificity, one depending on the phylogenetic relationships of the hosts and the other on their ecology.

\section{Morphological factors}

The greatest concentration of E. maculatum was found in the second and third chambers of the spiral valve intestine. It is possible that the cestodes are released in this location from the partially digested tissues of their intermediate hosts, as in many of the $R$. montagui that were examined a considerable amount of undigested food occurred in the first chamber of the intestine. Alternatively the larval cestodes may be liberated in other regions of the alimentary canal, in particular the stomach, and then undergo a migration or be carried to their normal habitat. It may be significant that the young stages of E. maculatum always contained, in their parenchymatous tissues, a high concentration of calcareous corpuscles and, as von Brand et al. (I960) have suggested, these may serve as a mechanism to counteract the high degree of acidity which is found in the stomach. The youngest specimens of E. maculatum found in the intestine of $R$. montagui indicated that the scolex of the parasite is in an advanced stage of development (Text-fig. 5) on infesting the host. The scolex of an adult worm (Text-fig. 4) which is liberating proglottides does not exhibit a significant difference in size and structure from that of the immature stage. In view of the fact that differences occur in the dimensions of the folds that constitute the mucosa of the gut as well as in the depths between these folds (Pl. I) it was thought possible that E. maculatum may seek an area of the gut to which it can attach itself most efficiently. For example, substantial variations occur in the depths between the folds at the anterior, middle and posterior regions of the intestine (Text-figs. 4-6), the average height of the primary folds measuring $\mathrm{I} \cdot \mathrm{IO}, 0.76$ and $0.24 \mathrm{~mm}$, respectively. However, since the average length of the loculate surface of the bothridium (in fixed specimens) is about $0.50 \mathrm{~mm}$, it is not obvious why bothridia attaching themselves in the manner illustrated in Text-fig. 9 could not become attached to the mucosa of any of the three regions of the spiral valve. On the other hand, 
it is evident that the size, shape and structure of the bothridium of this cestode appear to be perfectly adapted for attachment to this type of mucosa and not to an intestine like that of $R$. naevus where numerous villi are present. The proglottides of E. maculatum, the greatest concentrations of which occur in the anterior chamber of the intestine, would obviously find the greatest protection and possibly more nourishment in this position where the depth between the folds is at its maximum (Pl. I, fig. 4).

It is felt, therefore, that morphological factors of this nature should not be ignored in an explanation of the specificity of E. maculatum to $R$. montagui. As far as the writer is aware there are no previous accounts of morphological factors playing a role in the specificity of various tetraphyllideans to particular hosts and to precise habitats within the host. The above comments, therefore, have bearing on the remarks made by Shulman (1954) on the close contact and degree of morphological adaptation of the parasite to its host. He suggested that these may be significant factors affecting host-specificity which he regarded as one of the basic problems of contemporary parasitology. Llewellyn (1956) has also stated that in some of the Monogenea 'there is an exacting topographical relationship between parasite and host, and this is probably an important factor in the mechanism of host specificity'.

\section{TAXONOMY OF THE GENUS ECHENEIBOTHRIUM}

Euzet (1959) pointed out that the taxonomy of the Tetraphyllidea is in a state of chaos and made a valuable contribution towards solving many of the difficulties involved. Williams (I958a) in a preliminary account of some Tetraphyllidea from British elasmobranchs stated that little was known of the detailed structure of the scolex in Echeneibothrium and accepted Rhinebothrium Linton, I 890 as a synonym of the genus. Further work has now confirmed that in some species of Echeneibothrium the myzorhynchus may become completely retracted within the scolex, thus giving the impression that it is absent, but as already indicated by Williams (1958b) more detailed studies have now shown that Rhinebothrium is a valid genus.

Species of the genus Echeneibothrium found in British rays still present many taxonomic problems which, in the writer's opinion, can be solved only by further and more extensive work on the biology of these cestodes and their hosts, with due regard to the accurate identification of the fishes in which they are found, a task which is not always easy. Williams (I960) stated that some species of the genus Raia could be identified solely by an examination of the mucosa of the intestine and that occasionally $R$. clavata is confused with $R$. montagui. For example, a ray caught at Plymouth in August 1958 was provisionally labelled by the writer as 'either $R$. montagui or $R$. clavata, probably the former' but was only recently attributed to $R$. montagui after an examination of the intestine and its cestode parasites. In addition a recent 
re-examination of the intestine of a ray revealed that it had been wrongly labelled as $R$. montagui when caught by the writer in the Irish Sea in the spring of 1957 . The discovery that it was in fact $R$. clavata has contributed towards solving a problem regarding the parasites briefly described by Williams (1958 a as E. fallax. A cestode resembling E. fallax was present in this specimen of $R$. clavata but it occurred together with two other species of the genus Echeneibothrium both of which have now been found to be specific to this ray. The results obtained so far appear to indicate that in 'British' waters E. fallax, or a species with similar morphological features, is the only member of the genus which is not specific to a particular species of Raia. Further work is necessary either to confirm or disprove this suggestion. It is interesting to note, however, that the parasite now identified provisionally as E. fallax is never present in large numbers and stimulates a large amount of host-tissue reaction, facts which indicate that its scolex is not so well adapted for adhesion as it is in other members of the genus. The present investigation has shown that E. maculatum possesses $18-20$ loculi in each bothridium, 20 testes in each proglottid, and that it parasitizes $R$. montagui only. It is, therefore, a valid species and, as already suggested by Williams (1958b), it should not be included as a synonym of $E$. dubium, which has 1o loculi, 16 testes and is found in R. batis. It is hoped that more work along the lines described above will contribute towards solving many of the difficulties regarding the systematics of the genus Echeneibothrium.

I am very much indebted to the late Prof. T. A. Stephenson, F.R.S., and Dr Gwendolen Rees for every possible encouragement to commence the above work with the aid of a Department of Scientific and Industrial Research Fellowship. My thanks are also due to the Director and staff, in particular $\mathrm{Mr} \mathrm{J}$. Green and Mr A. Mattacola of the Plymouth Marine Laboratory, and to Prof. James Brough for providing excellent research facilities. Dr J. Llewellyn, of the University of Birmingham, has kindly read the manuscript and suggested many improvements. Mr W. O'Grady has given technical assistance for which I am most grateful.

\section{EXPLANATION OF PLATE I}

Raia montagui. Facial and vertical sections through the mucosa from various regions of the intestine, all magnified to the same scale.

Fig. I. First chamber.

Fig. 2. Third chamber where Echeneibothrium maculatum is usually attached.

Fig. 3. Last chamber.

Fig. 4. First chamber.

Fig. 5. Third chamber.

Fig. 6. Last chamber. 

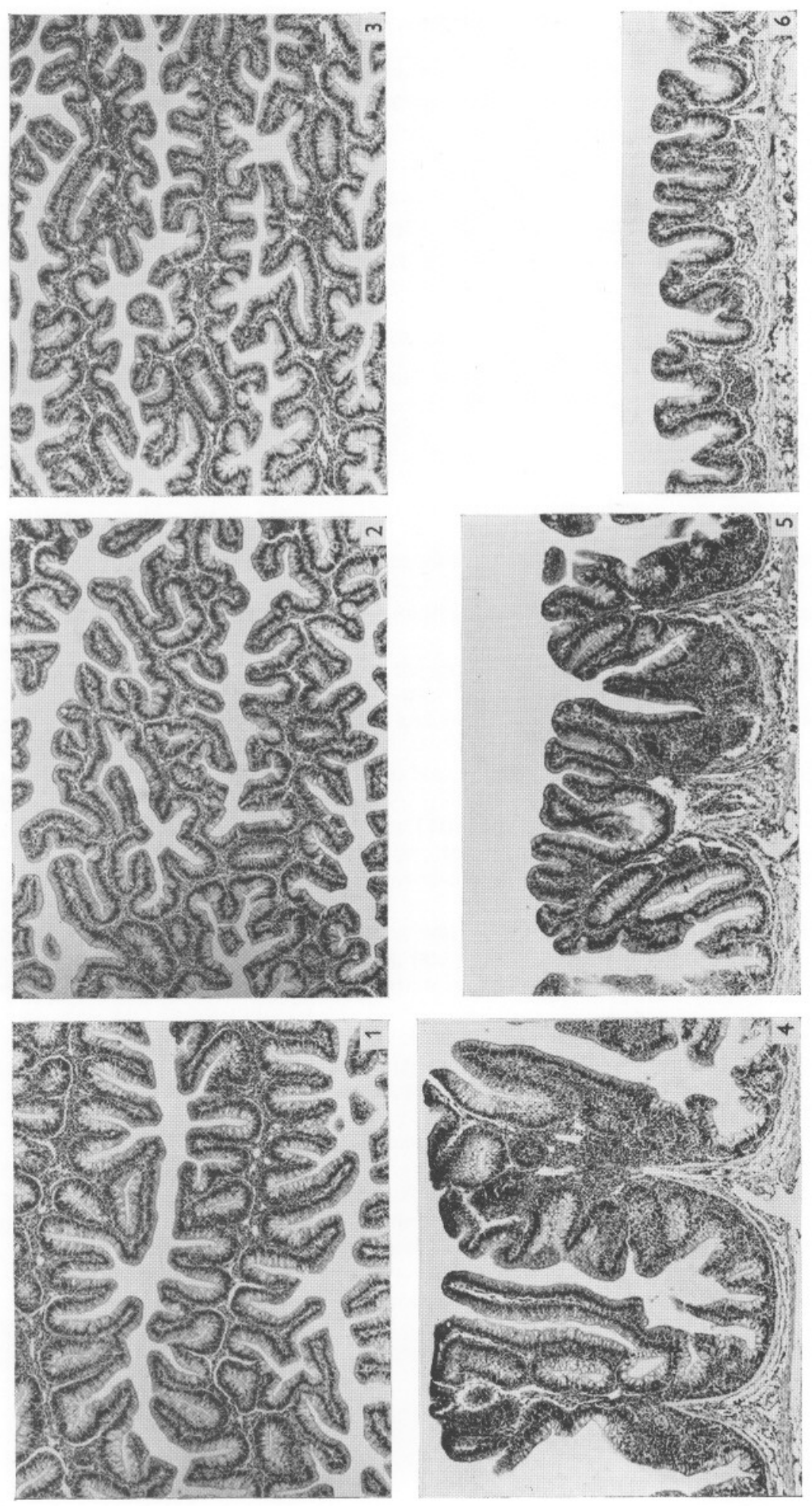

(Facing p. 650) 
Steven, G. A., I932. Rays and skates of Devon and Cornwall. II. A study of the fishery with notes on the occurrence, migrations and habits of the species. $\mathcal{F}$. mar. biol. Ass. U.K., Vol. 18, pp. I-34.

1947. The British Raiidae. Science Progress, Vol. 35, pp. 220-236.

Thompson, T. E., I958. Observations on the Radula of Adalaria proxima (A. \& H.) (Gastropoda Opisthobranchia). Proc. malac. Soc. Lond., Vol. 33, pp. 49-56.

von Brand, T., Mercado, T. I., Nylen, M. U. \& ScotT, D. B., I960. Observations on function, composition and structure of cestode calcareous corpuscles. Exp. Parasitol., Vol. 9, pp. 205-I4.

WILliams, H. H., I958a. Some Phyllobothriidae (Cestoda:Tetraphyllidea) of elasmobranchs from the western seaboard of the British Isles. Ann. mag. Nat. Hist., Ser. 13, Vol. I, pp. Ir3-36.

- 1958 $b$. Some Tetraphyllidea (Cestoda) from the Liverpool School of Tropical Medicine. Rev. suisse Zool., Vol. 65, pp. 865-78.

I960. The intestine in members of the genus Raja and host specificity in the Tetraphyllidea. Nature, Lond., Vol. I88, pp. 514-I6.

WooDLAND, W. N. F., I927. A revised classification of tetraphyllidean Cestoda, with descriptions of some Phyllobothriidae from Plymouth. Proc. zool. Soc. Lond., Vol. 2, pp. 519-48. 